\title{
NOWE TRENDY W KONSUMPCJI WE WSPÓŁCZESNYM SPOŁECZEŃSTWIE. REFLEKSJA SOCJOLOGICZNA
}

\section{NEW TRENDS IN CONSUMPTION IN CONTEMPORARY SOCIETY. SOCIOLOGICAL REFLECTION}

\author{
Olga Filipiak ${ }^{1(\mathrm{~A}, \mathrm{~B}, \mathrm{C}, \mathrm{D}, \mathrm{E}, \mathrm{F}, \mathrm{G})}$
}

${ }^{1}$ Zakład Socjologii, Państwowa Szkoła Wyższa im. Papieża Jana Pawła II w Białej Podlaskiej

\begin{abstract}
Filipiak, O. (2018). Nowe trendy w konsumpcji we współczesnym społeczeństwie. Refleksja socjologiczna. Rozprawy Społeczne, 12(4), 22 -27. https://doi.org/10.29316/rs.2018.33

Wkład autorów:

A. Zaplanowanie badań

B. Zebranie danych

C. Dane - analiza i statystyki

D. Interpretacja danych

E. Przygotowanie artykułu

F. Wyszukiwanie i analiza

literatury

G. Zebranie funduszy

Streszczenie

Celem artykułu jest scharakteryzowanie najpowszechniejszych tendencji występujących w konsumpcji we współczesnym społeczeństwie, co wpisuje się w obszar badawczy socjologii konsumpcji. Rozważania podjęte w artykule koncentrują się wokół problemu zmian, jakie zachodzą w sferze konsumpcji oraz ich konsekwencji odnoszących się do ładu społeczno-gospodarczego. Wykorzystano metodę przeglądu publikacji naukowych krajowych i zagranicznych związanych z tematyką badawcza, poprzez wyjaśnienie m.in. takich pojęć jak: konsumpcjonizm, prosumpcja, ekologizacja konsumpcji, democentryzacja konsumpcji, wirtualizacja konsumpcji, konsumpcja etyczna. Pozwoliło to wskazanie kierunku przemian zachodzących we współczesnej konsumpcji pod wpływem m.in. takich procesów i zjawisk społecznych jak: globalizacja, postęp technologiczny, czy zmiany cywilizacyjne. Skala i oddziaływanie tych trendów zależą od otoczenia ekonomicznego, społecznego, technologicznego i kulturowego społeczeństwa.
\end{abstract}

Tabele: 0

Ryciny: 0

Literatura: 16

Otrzymano: styczeń 2018

Zaakceptowano: kwiecień 2018
Słowa kluczowe: konsumpcja, trendy w konsumpcji, konsumpcjonizm, prosumpcja

\section{Summary}

The aim of the article is to characterize the most common tendencies that occur in consumption in contemporary society, which is part of the research area of consumption sociology. The considerations taken up in the article focus on the problem of changes taking place in the sphere of consumption and their consequences relating to the socio-economic order. The method of reviewing domestic and foreign scientific publications related to research topics was used by explaining, among others, such concepts as: consumerism, prosumption, ecologisation of consumption, democratization of consumption, virtualization of consumption, ethical consumption. It allowed to indicate the direction of changes taking place in contemporary consumption under the influence of, e.g., such social processes and phenomena as: globalization, technological progress, or civilization changes. The scale and impact of these trends depend on the economic, social, technological and cultural environment of society.

Keywords: consumption, consumption trends, consumerism, prosumption

\section{Wstęp}

Konsumpcja stanowi istotny element we współczesnym społeczeństwie i gospodarce, ale także wiąże się z ważnymi procesami kształtującymi obecny ład społeczno-gospodarczy na świecie. Postępujące procesy globalizacji, informatyzacji, rozwój nowych środków transportu nadają obecnej rzeczywistości zupełnie nowy kształt oraz pozwalają na stawianie coraz to nowych pytań dotyczących roli konsumpcji m.in. jako czynnika wzrostu gospodarczego. Konsumpcja w różnych jej wymiarach pełni wiele ważnych funkcji: gospodarczą (zapewnia efekty reprodukcyjne i motywacyjne dające możliwości wzrostu ekonomicznego) oraz społeczno-kulturalną (m.in. wpływa na jakość życia, system wartości, stratyfikację społeczną) (Olejniczuk-Merta, 2011, s. 17-20). Nie należy zapominać o podstawowej istocie konsumpcji jako procesu zaspokajania potrzeb człowieka, począwszy od tych podstawowych. Wydaje się, iż w tym aspekcie funkcja konsumpcji nie uległa zmianie. Pojawiły się jednak nowe znaczenia pozwalające rozpatrywać konsumpcję w innych wymiarach, jako atrybut prestiżu, luksusu, tożsamości.

Celem opracowania jest scharakteryzowanie wybranych trendów współczesnej konsumpcji, biorąc pod uwagę zmiany zachodzące w sferze konsumpcji oraz konsekwencje, jakie odnoszą się do ładu społeczno-gospodarczego. Zastosowana meto-

Adres korespondencyjny: Olga Filipiak, Zakład Socjologii, Państwowa Szkoła Wyższa im. Papieża Jana Pawła II w Białej Podlaskiej, ul. Sidorska 95/97, 21500 Biała Podlaska, e-mail: o.filipiak@wp.pl, tel.: 8334499 05, ORCID: https://orcid.org/0000-0003-0180-6914 Copyright by: Państwowa Szkoła Wyższa im. Papieża Jana Pawła II w Białej Podlaskiej, Olga Filipiak

Czasopismo Open Access, wszystkie artykuły udostępniane są na mocy licencji Creative Commons Uznanie autorstwa-użycie niekomercyjne-na tych samych warunkach 4.0 Międzynarodowe (CC BY-NC-SA 4.0, http://creativecommons.org/licenses/by-nc-sa/4.0/). 
da przeglądu publikacji krajowych, jak i zagranicznych pozwoliła na wyjaśnienie głównych pojęć oraz wskazanie nowych wyzwań związanych z trendami konsumpcji we współczesnym świecie.

Konsumpcja stanowi centrum zainteresowania wielu badaczy: ekonomistów, socjologów, antropologów. Nie sposób nie odnosić się do konsumpcji analizując przebieg innych znaczących procesów zachodzących w społeczeństwie i gospodarce. Postęp technologiczny i rozwój cywilizacyjny w istotny sposób wpływają na kształtowanie się nowych tendencji w sferze konsumpcji. Mamy do czynienia z nowym typem konsumentów, szybko reagujących na nowinki technologiczne i nastawionych na pełną realizację pragnień i zachcianek. Obecny porządek społeczny i gospodarczy związany jest ze zmianami, jakie zachodzą i które rzutują na ostateczny jego kształt. Ważnym czynnikiem jest wzrost mobilności ludzi, zarówno w celu zmiany miejsca zamieszkania, podjęcia nowej pracy, czy awansu społecznego. Procesy migracyjne zmieniają obraz współczesnego świata, co wpływa także na powolne zacieranie się różnic kulturowych oraz zmiany w systemie wartości, co widoczne jest w przyjmowanych stylach życia. Otoczenie ekonomiczne, polityczne, technologiczne, społeczne i kulturowe wywiera istotny wpływ na kształtowanie postaw konsumenta w obecnym czasie.

\section{Nowe trendy}

Konsumpcjonizm to jeden $\mathrm{z}$ najważniejszych trendów we współczesnej konsumpcji. W literaturze przedmiotu zwraca się uwagę na kilka istotnych aspektów konsumpcjonizmu, opisując go jako: sposób życia umożliwiający manifestację aktów konsumpcji w sferze kulturowej; atrybut współczesnej tożsamości człowieka; zjawisko psychospołeczne, czy też jako formę uzależnienia od dóbr materialnych i usług (Wątroba, 2006, s. 166-167). Wraz z rozwojem kultury masowej, postępującym procesem globalizacji nastąpiły zmiany we wzorach konsumowania, modzie, czy gustach konsumenckich. Wytworzył się tym samym nowy model traktowania konsumpcji jako celu samego w sobie, nie tylko jako sposobu zaspokajania potrzeb człowieka. Widoczne jest to w utrwalających się mechanizmach postępowania konsumentów oraz zmianie ich sposobu życia. W praktyce życia codziennego mamy do czynienia $\mathrm{z}$ nadmierną konsumpcją. Konsumpcjonizm nie liczy się z kosztami jednostkowymi, społecznymi, czy globalnymi. Pojawia się coraz więcej nowych form konsumpcjonizmu m.in.: zakupoholizm, infantylizacja konsumentów, tendencja „tu i teraz”, hedonizm i utylitaryzm. Konsumpcjonizm staje się niejako nową religią, a centra handlowe miejscami, w których toczy się nieustający spektakl konsumpcji (Ritzer, 2004).

Warto zwrócić uwagę na pogłębiający się trend dematerializacji konsumpcji. Wśród współczesnych konsumentów coraz częściej występuje reorien- tacja na wartości niematerialne, takie jak: wiedza, informacja, edukacja, kultura. Wraz z nastawieniem na te nowe wartości wrasta zapotrzebowanie na usługi w tym zakresie. Nie oznacza to jednak, iż konsumenci rezygnują z zakupu produktów i usług, które mają wyraźną wartość użytkową dla nich. Można jednak zauważyć, iż coraz częściej konsument dokonujący zakupów wybiera dane dobro kierując się jego wartością symboliczną. Jak podkreśla J. Baudrillard „wielu ludzi określa swoją tożsamość i komunikuje ją innym przez czynności konsumpcyjne, uprawiany sport, zamiłowanie bądź ulubioną muzykę, a nie przez swój zawód" (van Raaij, 2001, s. 339). To nowy wymiar konsumpcji postmodernistycznej.

Pamiętać należy, iż współczesna kultura konsumpcyjna opiera się na kulcie nowości i gadżetyzacji. Trwałość produktów jest coraz krótsza, nowsze wypierają stare modele w bardzo krótkim okresie czasu. Właściwie wydaje się, że nie ma dóbr trwałych, które mogłyby służyć człowiekowi przez dłuższy czas. Ciekawej konstatacji tego problemu dokonuje A. Toffler podkreślając, iż w zasadzie nasz stosunek do rzeczy odzwierciedla zmiany, jakie nastąpiły ma poziomie ludzkich wartości, gdzie istnieje „kontrast między przeszłością a przyszłością: między społeczeństwami opartymi na trwałości a nowym, szybko powstającym społeczeństwem opierającym się na krótkowzroczności" (Toffler, 1998, s. 60, za: Hostyński, 2006, s. 109). Liczy się natychmiastowe zaspokajanie swoich potrzeb i zachcianek, często zgodnie z zasadą „buy now, pay later" (kupuj teraz, płać później).

\section{Nowe sposoby konsumpcji}

Trendem, który rozwija się od początku XXI wie$\mathrm{ku}$ jest wirtualizacja konsumpcji. Coraz większe tempo życia, zwiększająca się ilość czasu spędzanego w pracy oraz rozwój nowych środków komunikacyjno-informacyjnych przyczyniają się do wzrostu tej tendencji. Można zatem powiedzieć, że obecnie mamy do czynienia z nowym typem konsumenta, który nie musi wychodzić z domu, a zaspokajanie jego potrzeb coraz częściej odbywa się za pomocą Internetu, czy TV. Nowe środki przekazu utrwalają ten sposób konsumpcji. W praktyce życia codziennego coraz częściej można zaobserwować tzw. showrooming, czyli oglądanie w sklepie tradycyjnym produktów $\mathrm{z}$ jednoczesnym poszukiwaniem informacji w Internecie dotyczących danego produktu z ostatecznym sfinalizowaniem zakupu w sieci (Sowa, 2015, s. 123). Tendencja ta szczególnie widoczna jest wśród młodych konsumentów, dla których wizyta w stacjonarnym sklepie np. ze sprzętem elektronicznym, daje możliwość fizycznego obejrzenia interesującego przedmiotu, który potem zakupiony jest poprzez Internet. To nowy sposób podejmowania decyzji zakupowych bez konsultacji ze sprzedawcą, czy doradcą. Wirtualizacja konsumpcji przyczynia się do powstania nowego trendu wśród 
konsumentów, jakim jest multitasking określany jako wielozadaniowość, pozwalający konsumentowi na korzystanie $\mathrm{w}$ tym samym czasie $\mathrm{z}$ różnych mediów (Internetu, TV, odtwarzaczy do słuchania muzyki, komunikatorów, telefonów komórkowych, czy innych urządzeń mobilnych). Zdaniem T. Zalegi istotą tego trendu jest „symultaniczne wykonywanie wielu czynności w tym samym czasie i jest efektem postępującego procesu globalizacji i internacjonalizacji gospodarki światowej" (Zalega, 2012, s. 131). Innymi słowy w tym samym czasie możemy jednocześnie dokonywać zakupów online, oglądać telewizję, słuchać muzyki, rozmawiać przez telefon, kontaktować się przez komunikatory internetowe, czy spożywać posiłek.

Innym ważnym trendem jest serwicyzacja związana z rozwojem rynku usług. Serwicyzacja konsumpcji wyraźnie wyznacza wzorce zachowań konsumentów oraz ich style życia, a także świadczy o poziomie i standardzie konsumpcji w gospodarstwie domowym (Zalega, 2012, s. 129). Uznając fakt, iż serwicyzacja dotyczy coraz większej ilości konsumentów w skali globalnej do najważniejszych czynników wpływających na dynamikę tego procesu należy zaliczyć: rodzaj usługi; sposób dystrybucji oraz formę odpłatności (bądź też jej brak); poziom zamożności gospodarstw domowych; cenę dóbr konsumpcyjnych; stopień postępu cywilizacyjnego i kulturowego; cechy osobowościowe konsumenta oraz procesy demograficzne zachodzące we współczesnych społeczeństwach (Bywalec, 2010, s. 200-201).

\section{Nowe spojrzenie na konsumpcję}

Zauważyć należy rozpowszechniający się trend, jakim jest etnocentryzm konsumencki, który oznacza „przekonania podzielane przez konsumentów na temat powinności i moralności kupowania artykułów pochodzenia krajowego" (Sowa, 2015, s. 120). Tego typu konsumenci wybierają produkty krajowe argumentując ten fakt dbałością o rodzimą gospodarkę i jej rozwój. W literaturze przedmiotu etnocentryzm konsumencki określany jest także jako przejaw patriotyzmu, uwarunkowany takimi czynnikami jak: cechy demograficzno-społeczne (wiek, płeć, wykształcenie); indywidualne potrzeby konsumenta oraz jego doświadczenia rynkowe; cechy osobowościowe konsumenta oraz wpływ społeczny na jego zachowania; uwarunkowania ekonomiczne (stopień rozwoju gospodarczego) oraz uwarunkowania polityczne (Angowski, Lipowski, 2014, s. 4-5). Jak zauważa L. Rudnicki (Rudnicki, 2012, s. 94) postawa etnocentryzmu konsumenckiego dotyczy zazwyczaj grup społecznych, których jakość życia i źródło utrzymania są zagrożone przez zagraniczną konkurencję. W ramach etnocentryzmu konsumenckiego konsument podejmuje decyzje o zakupie traktując ten fakt jako swoistego rodzaju wybór moralny. Trend ten może przyjmować bardzo skrajne formy np. bezrefleksyjną negację wszystkich produktów zagranicznego pochodze- nia. Jednakże wydaje się za zasadne uznanie iż, etnocentryzm konsumencki szczególnie ten w formie umiarkowanej stanowi realizację jednego $\mathrm{z}$ podstawowych praw konsumenckich, jakim jest prawo do wyboru. Należy podkreślić, iż konsumenckie postawy etnocentryczne związane są ze wzrastającym poziomem świadomości konsumenckiej.

W podobnej perspektywie można mówić o nowej tendencji w konsumpcji, jaką jest dekonsumpcja rozumiana jako „świadome i celowe ograniczenie wolumenu konsumowania produktów i usług do racjonalnych poziomów" (Zalega, 2012, s. 127). Jest to efektem powolnego odchodzenia świadomych konsumentów od nadmiernego nabywania dóbr konsumpcyjnych. Dekonsumpcję możemy rozpatrywać w czterech wymiarach: ograniczania konsumpcji ze względu na zaniepokojenie konsumentów w gospodarstwach domowych (konsumpcja asekuracyjna); ograniczanie ilościowe konsumpcji z jednoczesnym wzrostem nastawienia na jakość produktów i usług; przesuwanie się konsumpcji w stronę niematerialną oraz racjonalizację dotychczasowych wzorów konsumpcji (Rachocka, 2017). Należy jednak pamiętać, iż ta tendencja uzależniona jest od poziomu świadomości konsumenckiej, indywidualnych cech osobowości konsumenta, a także systemu wartości i zmian, jakie zachodzą w tym obszarze wśród konsumentów. Coraz bardziej popularne stają się koncepcje będące w opozycji do nadmiernej konsumpcji opierające się na haśle „powoli” czyli slow, które odnosi się nowego sposobu żywienia (slow food), nowego modelu pracy (slow work), nowego typu komunikacji społecznej (slow e-mail), czy nowych form organizacji przestrzeni mieszkalnej (slow city) (Bywalec, 2010, s. 217). W sferze medialnej coraz bardziej popularna staje się telewizja celebrująca upływ czasu (slow TV) z nowym rodzajem przekazu medialnego, w turystyce zaś - slow travel, czyli powolne podróżowanie, czy slow shopping jako rozsądne zakupy. A. Duda zwraca uwagę na ciekawy trend, jakim jest downshifting, który należy rozumieć jako świadomą rezygnację z części dóbr materialnych, dzielenie się nimi, poszukiwanie rzeczy używanych, ale również są to zmiany widoczne w stylu życia, sferze zawodowej (np. porzucanie prestiżowych stanowisk i wysokich wynagrodzeń na rzecz pracy wykony wanej za mniejsze pieniądze, jednak z zachowaniem większej swobody)(Duda, 2016, s. 429). Tak pojmowana prostota życia, poszukiwanie spełnienia, troska o zdrowie nie wyklucza jednocześnie korzystania z nowych technologii, czy zupełnego pozbycia się rzeczy materialnych. To dość ciekawa propozycja, którą z uwagą należy śledzić na współczesnym rynku konsumenckim.

Nowym trendem staje się powoli democentryzacja konsumpcji polegająca na świadomej rezygnacji z korzystania z publicznych instytucji do zaspokajania potrzeb przez konsumentów . Jak podaje S. Smyczek do czynników sprzyjających democentryzacji możemy zaliczyć: postęp technologiczny; polepszenie się warunków mieszkaniowych i finansowych 
w gospodarstwach domowych; coraz lepsze wyposażenie mieszkań w sprzęt RTV i AGD, ale także wpływ czynników społecznych związanych z postępującą indywidualizacją i wzrastającym znaczeniem prywatności (Smyczek, 2015, s.106). Innymi słowy wyraźnie kreuje się grupa konsumentów, która chętniej zostaje w domu i tam realizuje swój model aktywności konsumenckiej, rekreacyjnej, czy edukacyjnej. G. Ritzer wskazuje, że to „dom stał się jednym z głównych miejsc, a może nawet głównym miejscem nabywania towarów" (Ritzer, 2004, s. 245).

\section{Współczesne wyzwania}

Jednym z symptomów wzrastającej świadomości konsumenckiej jest postępująca ekologizacja konsumpcji. Ekologizacja konsumpcji to nade wszystko działania w obszarze racjonalnego i oszczędnego wykorzystywania dóbr konsumenckich, wyboru produktów ekologicznych, biodegradowalnych i łatwo poddających się recyklingowi oraz unikanie tych produktów, które pochodzą z niehumanitarnych hodowli zwierząt oraz powstałych w wyniku pracy niewolniczej i pracy dzieci (Bywalec, 2010, s. 196). Wydaje się, że najlepszym sposobem do kształtowania nowych postaw w tym zakresie jest edukacja ekologiczna, która wdrażana systematycznie i skutecznie pozwoliłaby na wykształcenie nowych nawyków ekologicznych zmieniających dotychczasowe oblicze współczesnego konsumenta. Podstawowe elementy związane z kwestiami dotyczącymi m.in. ochrony środowiska, a także ekokonsumpcji powinny być wdrażane w programach edukacyjnych już w grupach przedszkolnych i wczesnoszkolnych. Uczenie dzieci poszanowania środowiska naturalnego, w którym żyją oraz najbliższego otoczenia wymaga systematycznej i dostosowanej do grupy odbiorców ścieżki edukacji ekologicznej. Realizacja nawet najmniejszych działań związanych z ekologią przyczynia się do kształtowania świadomego i odpowiedzialnego konsumenta.

Nowy trend w zachowaniach konsumenckich to tzw. konsumeryzm etyczny postulujący traktowanie wyboru produktu lub usługi w kategoriach etycznych $\mathrm{z}$ pełną świadomością (Lewicka-Strzałecka, 2003, s.132-138). Konsumowanie w tym podejściu traktowane jest jako wybór moralny w odniesieniu do sposobu wytworzenia, sprzedaży, czy dystrybucji. Etyczna konsumpcja wymaga bardzo świadomego podejścia oraz wysokiego poczucia odpowiedzialności w dokonywanych przez konsumenta wyborach. Szczególną uwagę należy zwrócić na problem pracy dzieci w krajach z prężnie rozwijającą się gospodarką np. w Indiach. Mamy tam często do czynienia $\mathrm{z}$ formą współczesnego niewolnictwa, gdzie dzieci zmuszone są do pracy w nieludzkich warunkach i za minimalną zapłatę. Traca tym samym możliwości edukacji i rozwoju pozostając w tragicznych warunkach mieszkaniowych i życiowych. Dlatego etyczne podejście do konsumpcji zwraca uwagę na te okoliczności związane z produkcją dóbr, które codziennie użytkujemy jako konsumenci.

Współczesny konsument funkcjonuje w zglobalizowanym świecie, co wpływa na postawy konsumenckie oraz realizowanie odpowiednich stylów życia. Obecnie można zauważyć zjawiska pogłębiające proces homogenizacji konsumpcji (Bywalec, 2010, s. 206-207), do których należy zaliczyć: globalizację gospodarki i kultury; mobilność społeczeństwa w układzie przestrzennym (przemieszczanie się w celach turystycznych, zarobkowych) i w strukturze społeczno-zawodowej; wzrost znaczenia wielkich ośrodków miejskich; zmiany demograficzne; ujednolicanie się stylów życia wraz z odchodzeniem od wartości tradycyjnych; standaryzację produktów; zwiększającą się ilość centrów handlowych; rozwój Internetu i nowych środków komunikacji. Zjawiska te i procesy przenikają wiele obszarów życia człowieka determinując jego wybory konsumenckie, zmiany w sytuacji społeczno-zawodowej, czy też sposób spędzania czasu wolnego i przyjmowania określonych wzorów konsumpcji. Globalizacja kształtuje sferę konsumpcji, mówi się nawet o zacieraniu się granic, które dotychczas pozwalały na rozróżnienia w tym obszarze. Postępująca dyfuzja wzorców zachowań, ujednolicanie się sposobów konsumowania, spędzania czasu wolnego to widoczne efekty wpływu globalizacji. Obecnie w większości krajów o średnim i wysokim poziomie rozwoju gospodarczego i cywilizacyjnego konsumuje się podobne produkty, korzysta się z tych samych usług, pracuje się i podróżuje w podobny sposób. Dzięki rozwojowi nowych technologii, szczególnie Internetu większość społeczeństw w skali globalnej ma dostęp do informacji oraz niczym nieograniczonej komunikacji międzyludzkiej. Pomimo tego, należy jednak pamiętać o stale pogłębiających się nierównościach społecznych w skali globalnej. Dotyczą one wielu sfer życia: sytuacji ekonomicznej, politycznej, szans życiowych, czy nawet braku możliwości zaspokajania podstawowych potrzeb. Dysproporcje te stale się utrzymują, a nawet pogłębiają. $\mathrm{Z}$ jednej strony mamy do czynienia z konsumentem, który ma nieograniczony dostęp do dóbr i usług, pracy, zaś z drugiej strony ludzi, którym brakuje środków do codziennego życia, bez dostępu do służby zdrowia, edukacji . Ubóstwo to także współczesny obraz konsumpcji, gdzie szczególnie widoczny jest podział na biednych i bogatych.

Odmiennym zjawiskiem od homogenizacji konsumpcji jest heterogenizacja, której widocznym efektem jest indywidualizacja $w$ zachowaniach konsumenckich odznaczająca się chęcią zachowania własnego stylu i własnych preferencji. Podkreślenie indywidualności, kreatywności, a także duże możliwości wyboru wpływają na kształtowanie się nowej roli konsumenta bardziej świadomego. Obecnie coraz bardziej wyraźnie rysuje się tendencja indywidualizacji konsumentów. To nastawienie widoczne jest w pogłębiającym się trendzie dopa- 
sowywania produktów i usług do potrzeb i oczekiwań konsumentów.

W analizie tendencji konsumenckich szczególne miejsce zajmuje zjawisko prosumpcji. Amerykański socjolog i futurolog A. Toffler pisze: „Produkcja i konsumpcja zbiegają się ze sobą tworząc prosumpcję" (van Raaij, 2001, s. 332). Zacierają się powoli granice między konsumentem i producentem pod wpływem m.in. wzrastającej ilości czasu wolnego będącego efektem postępującej automatyzacji i robotyzacji procesu produkcji; pojawienia się możliwości wykonywania pracy zawodowej w domu; rozwoju edukacji i wzrostu znaczenia wykształcenia permanentnego oraz zmiany w organizacji pracy i podejściu do niej poprzez nastawienie na twórczość i samorealizację (Bywalec, 2010, s.221). Wytworzył się nowy typ relacji konsument - producent, gdzie ten pierwszy ma coraz większy wpływ na powstawanie produktów już $w$ fazie ich koncepcji. Nie jest to jednak zjawisko nowe. W historii rozwoju gospodarczego i wynalazczości można odnaleźć kreatywne rozwiązania wprowadzane przez konsumentów, na przykład: w Anglii na początku XIX wieku producenci maszyn parowych prowadzili stałą współpracę z właścicielami kopalń; w USA w latach 70-tych XX rozwinięto stałe konsultacje wśród użytkowników i inżynierów, czego efektem było wyprodukowanie pierwszego komputera, czy masowa produkcja stali (Tapscott, Williams, 2008,s.188). Konsumenci niejednokrotnie mieli wpływ na udoskonalanie wyrobów podnosząc ich nowatorskość i innowacyjność, ale tego rodzaju praktyki odbywały się w sposób sporadyczny, zaś dzisiaj tendencja ta jest wprowadzana na większą skalę.

\section{Podsumowanie i wnioski}

Analiza nowych trendów w konsumpcji pozwoliła na wyjaśnienie złożoności tych zjawisk oraz stwierdzenie, iż występują one jednocześnie w różnych konfiguracjach, mają różny wymiar. Należy jednak podkreślić, iż skala i oddziaływanie tych tendencji uzależnione są od otoczenia ekonomicznego, społecznego, technologicznego i kulturowego, w którym się rozwijają. Na rozwój nowych tendencji w sferze konsumpcji ma wpływ wiele czynników. Przeformułowania, jakie zachodzą w sferze konsumpcji zależne są od rozwoju gospodarczego danego kraju oraz modelu gospodarki w nim realizowanego. Wpływa to na decyzje nabywcze podejmowane przez konsumentów oraz na sytuację ekonomiczną gospodarstw domowych. Duże znaczenie ma sytuacja demograficzna, struktura społeczno-zawodowa i zmiany, jakie zachodzą w procesach ludnościowych, chociażby pojawiający się problem starzejącego się społeczeństwa. Ponadto zmiany w sferze kulturowej oraz w systemie wartości, norm społecznych kształtują współczesnego konsumenta. Stąd także autorce opracowania przyświecała idea przeanalizowania współczesnych trendów w konsumpcji oraz próba powiązania tych tendencji z innymi ważnymi procesami kształtującymi rzeczywistość społeczno-gospodarczą współczesnego świata. Omówione trendy pozwoliły na przedstawienie tego istotnego wymiaru teraźniejszości. Ważne by nie traktować konsumpcji w oderwaniu od pozostałych istotnych procesów kształtujących rzeczywistość społeczną.

\section{Literatura:}

1. Angowski, M., Lipowski, M. (2014). Uwarunkowania wyboru produktów żywnościowych i miejsc ich zakup. Pobrane z: http://researchgate.net/profile/Marek_Angowski/publication

2. Bywalec, Cz. (2010). Konsumpcja a rozwój gospodarczy i społeczny. Warszawa: Wydawnictwo C.H.Beck.

3. Duda, A. (2016). Konsumpcja. Teorie i badania. Lublin: Wydawnictwo KUL.

4. Hostyński, L. (2006). Wartości w świecie konsumpcji. Lublin: Wydawnictwo UMCS.

5. Lewicka-Strzałecka, A. (2003). Konsumeryzm kontra konsumeryzm. Annales. Etyka w Życiu Gospodarczym, 6, 132-138.

6. Olejniczuk-Merta, A. (2011). Konsumpcja we współczesnej gospodarce. W: A. Kusińska (red.), Konsumpcja a rozwój społeczno-gospodarczy regionów w Polsce (s. 13-30). Warszawa: PWE.

7. Rachocka, J. (2003). Dekonsumpcja, democentryzm, ekologizacja życia - nowe tendencje konsumenckie w rozwiniętych gospodarkach rynkowych. Pobrane z: http://docplayer.pl/7508412-Dekonsumpcja-domocentryzm-ekologizacja-zycia-nowe-tendencje-konsumenckie-w-rozwinietych-gospodarkach-rynkowych.html.

8. Rudnicki, L. (2012). Zachowania konsumentów na rynku. Warszawa: PWE.

9. Ritzer, G. (2004). Magiczny świat konsumpcji. Warszawa: Warszawskie Wydawnictwo Literackie MUZA S.A.

10. Sowa, I. (2015). Nowe trendy w zachowaniach młodych konsumentów. W: E. Kieżel, S. Smyczek (red.), Zachowania konsumentów. Procesy unowocześniania konsumpcji (s. 119-152). Warszawa: Wydawnictwo Kluwer SA.

11. Smyczek, S. (2015). Przejawy unowocześniania konsumpcji na rynkach finansowych. W: E. Kieżel, S.Smyczek (red.), Zachowania konsumentów. Procesy unowocześniania konsumpcji (s. 97-118). Warszawa: Wydawnictwo Kluwer S.A.

12. Tapscott, D., Williams, A.D. (2008). Wikinomia. O globalnej współpracy, która zmienia wszystko. Warszawa: Wydawnictwa akademickie i profesjonalne. 
13. Toffler, A. (1998). Szok przyszłości. Poznań: Wydawnictwo Zysk i S-ka.

14. van Raaij, F. (2001). Konsumpcja postmodernistyczna. W: M. Lambkin, G. Foxall, F. van Raaij, B.Heilbrunn (red.), Zachowanie konsumenta. Koncepcje i badania europejskie (s. 324-344). Warszawa: Wydawnictwo Naukowe PWN.

15. Wątroba, W. (2006). Społeczeństwo konsumpcyjne w dobie globalizacji. Wrocław: Wydawnictwo Akademii Ekonomicznej we Wrocławiu.

16. Zalega, T. (2012). Konsumpcja. Determinanty-teorie-modele. Warszawa: Wydawnictwo PWE. 